OPEN ACCESS

Edited by:

Daniel Munblit,

I. M. Sechenov First Moscow State

Medical University, Russia

Reviewed by:

Yoshinori Morita

Chiba University, Japan Meghan B. Azad

University of Manitoba, Canada

*Correspondence:

Kirsi M. Järvinen

Kirsijarvinen-seppo@

URMC.Rochester.edu

Specialty section:

This article was submitted to

Pediatric Immunology,

a section of the journal

Frontiers in Pediatrics

Received: 01 May 2018

Accepted: 16 July 2018

Published: 07 August 2018

Citation:

Rajani PS, Seppo AE and Järvinen KM (2018) Immunologically Active Components in Human Milk and

Development of Atopic Disease, With

Emphasis on Food Allergy, in the

Pediatric Population.

Front. Pediatr. 6:218

doi: 10.3389/fped.2018.00218

\section{Immunologically Active Components in Human Milk and Development of Atopic Disease, With Emphasis on Food Allergy, in the Pediatric Population}

\author{
Puja S. Rajani, Antti E. Seppo and Kirsi M. Järvinen*
}

Division of Pediatric Allergy and Immunology and Center for Food Allergy, University of Rochester School of Medicine and Dentistry, Rochester, NY, United States

Breast-feeding is currently recommended to prevent the development of allergic diseases; however, data are conflicting and mechanisms are unclear. The immunomodulatory composition of human milk is poorly characterized and varies between mothers. We and others have shown that high levels of human milk IgA and certain cytokines and human milk oligosaccharides are associated with protection against food allergy in the infant, but it is unclear whether they are responsible for or simply biomarkers of the vertical transfer of protection. Because human milk has pre- and probiotic properties, the anti-allergy protection afforded by human milk may be due to its control on the developing gut microbiome. In mice, murine milk IgA supports gut homeostasis and shapes the microbiota, which in turn diversifies the intestinal IgA repertoire that reciprocally promotes the diversity of gut microbiome; these mechanisms are poorly understood in humans. In addition, several human milk bioactives are immunostimulatory, which may in part provide protection against allergic diseases. The regulation of immunologically active components in human milk is incompletely understood, although accumulating evidence suggests that IgA and cytokines in human milk reflect maternal exposures. This review summarizes the current literature on human milk components that have been associated with protection against food allergy and related allergic disorders in early childhood and discusses the work relating to regulation of these levels in human milk and possible mechanisms of action.

Keywords: breast milk composition, breast feeding, atopic development, IgA, breast milk microbiome, cytokines, human milk oligosaccharides (HMOs), fatty acids

\section{INTRODUCTION}

Breast-feeding is a natural process of providing nourishment to offspring. Human milk is the optimal source of nutrition for term infants during the first 6 months of life as it provides nutrients, antimicrobial factors, and exposure to important immunomodulatory factors infants need to grow, develop, and thrive (1). There are various studies showing that human milk provides defense against infections and development of allergic disease $(2,3)$. The first few months of life are a crucial window in which the still-developing infant immune system can be influenced, with 
breast-feeding allowing for continued exposure to the mother's immune system. This can impact oral tolerance induction and development of allergy (Figure 1). However, the immunomodulatory composition of human milk is poorly characterized and varies between mothers.

Many studies have been published investigating the effect of breastfeeding on atopic diseases, though conclusions from these studies were conflicting, with some authors claiming a protective effect, some remaining undecided, and a few even suspecting that breastfeeding might promote the development of atopic diseases (4-6). Systematic reviews and meta-analyses have concluded an overall protective effect of breastfeeding against atopic dermatitis, wheezing/asthma, allergic rhinitis and cow's milk allergy (CMA) in early childhood (7-10), and breast-feeding is currently recommended to prevent allergic diseases (11). A multidisciplinary review of the literature from 1966-2001 by van Odijk et al. reviewed 132 articles discussing early feeding methods and outcome of atopic disease (7). Only 56 of these articles were conclusive and the conclusion of the reviewers was that breastfeeding is protective of atopic diseases (asthma, recurrent wheezing, atopic dermatitis), and the protective impact is stronger in children with atopic heredity. The review also concluded that exposure to small doses of cow's milk during first days of life predisposes to cow's milk allergy (CMA), and in children with atopic heredity, breastfeeding and extensively hydrolyzed formula protect against CMA. A meta-analysis by Gdalevich et al. in 2001 showed that at least 3 months of exclusive breastfeeding protected from eczema and asthma in children with a family history of atopy $(12,13)$. Development of food allergy was not assessed. This has been reproduced in various other observational studies from Australia, Sweden, and Denmark. (14-16). The Promotion of Breastfeeding Intervention Trial (PROBIT), a large randomized trial from Belarus, was able to promote breastfeeding duration and exclusivity of breastfeeding at 16 hospitals and found that at these sites, infants had fewer gastrointestinal infections and lower incidence of eczema in the first year of life (17). However, the follow-up at 6 years of this same cohort showed a lack of protective effect with this intervention on asthma, eczema, or hay fever (5). The American Academy of Pediatrics Committee on Nutrition and Section on Allergy and Immunology published a clinical report in 2008 concluding that there is evidence that breastfeeding until 4 months, compared with feeding formula made with intact cow's milk protein, prevents (or delays) the occurrence of atopic dermatitis, wheezing and cow's milk allergy in early childhood (9). Interestingly, Katz et al. reported in 2010 in a large-scale prospective population-based study that early exposure to cow's milk protein as supplementation to breastfeeding might prevent IgE-mediated cow's milk protein allergy (18). The Cochrane Database Systematic Review in 2012 by Kramer and Kakuma (3) concluded that with breastfeeding beyond 3-4 months, there is no significant reduction in risk of atopic eczema, asthma, or other atopic outcomes demonstrated in studies from Finland, Australia, and Belarus. This was confirmed to be the case for eczema in the retrospective ISAAC Phase Two Study of $>51,000$ children randomly selected in 21 countries (19). The most recent systematic review by Lodge et al. from 2015 showed the protective effect of more vs. less breastfeeding against risk of asthma in children 5-18 years, especially in lower income countries, and against allergic rhinitis in children $\leq 5$ years (10). There was a

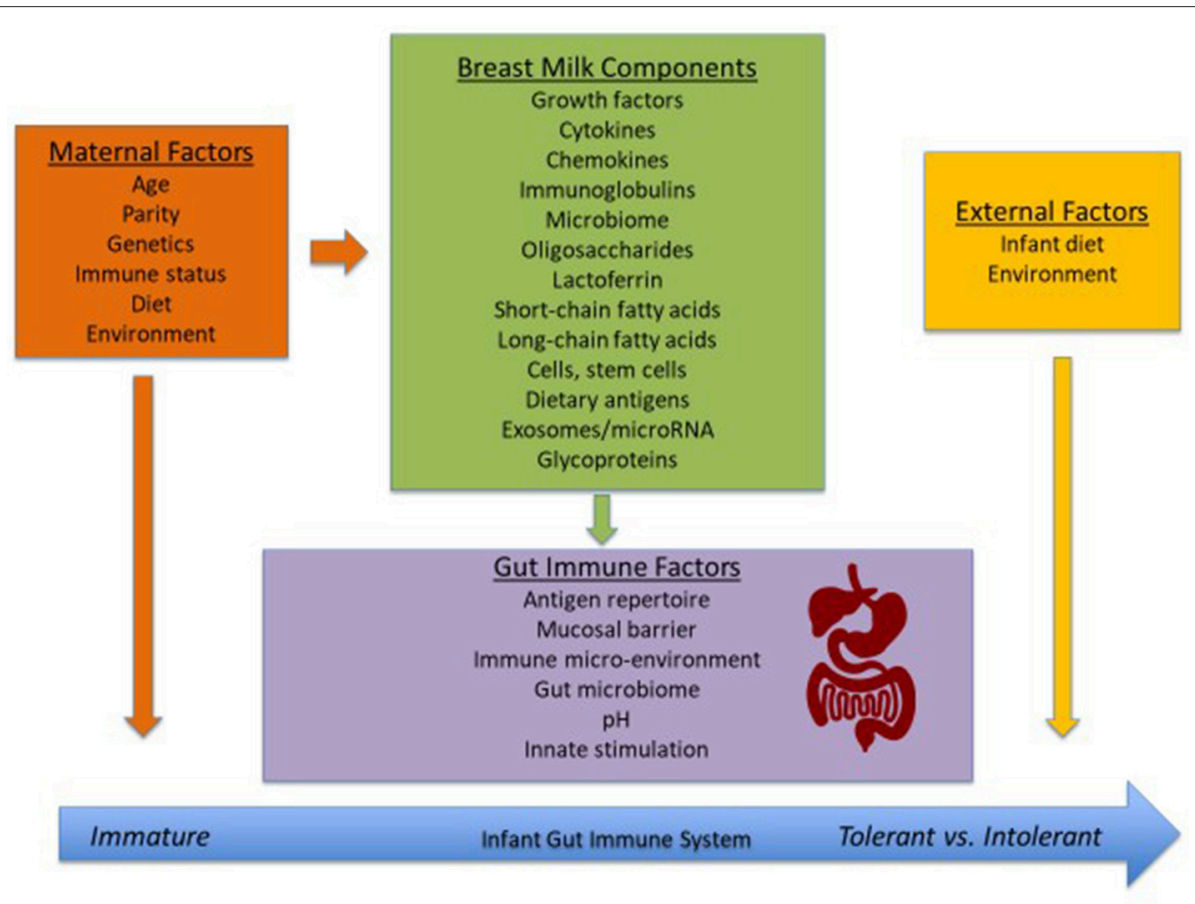

FIGURE 1 | Factors that influence the development of the neonatal immune system. 
significant effect of protection against eczema for children $\leq 2$ years by exclusive breastfeeding for 3-4 months. Estimate for an effect of breastfeeding on food allergy had high heterogeneity and low quality. Most recently, a retrospective study in 2016 from Japan noted that cow's milk formula exposure during the first 3 months of life may also have a protective effect on CMA (20). However, data are conflicting, especially given the lack of randomized controlled trials and varied definitions of breastfeeding and allergic outcomes. Unfortunately, most studies have been underpowered for food allergies or not assessed at all due to methodologic problems of making the firm diagnosis. However, among all the atopic diseases, breastfeeding may have the most impact on development of oral tolerance to foods, which develops in the gastrointestinal tract. Epidemiologic studies have not accounted for the human milk composition, which varies from one mother to another, and may be a remarkable confounder impacting its protective properties.

Human milk impacts the development of the infant gut microbiome, along with other maternal and environmental factors. At birth the infant transitions from a highly regulated maternal, microbiota-scarce environment to becoming colonized with ex utero microbiota (21). With vaginal birth, the infant microbiota originates mainly from the mother's intestine, vagina and skin, while the hospital environment and the mother's skin provide the first colonizing microbes with $\mathrm{C}$-section birth (21-23). The bacterial colonization of the newborn intestine may contribute to development of the neonatal immune functions or susceptibility to immune-mediated disorders in early (and later) life $(6,24,25)$. Evidence from both animal (26) and human studies (27-31) have reported that gut dysbiosis precedes the development of atopy, atopic eczema and food allergy/sensitization. In the past year, several studies have linked the importance of gut microbiome and food allergy. Kourosh et al. sought to better understand fecal microbiome in children with $\mathrm{IgE}$ mediated food allergy and were able to show that there were significant differences in microbial composition amongst food-allergic children, especially in the Clostridia class, compared with healthy siblings and healthy children (32). Fieten et al. looked for differences in fecal microbiome in children with or without food allergy in the setting of atopic dermatitis (33). Their pilot study showed significant differences in the microbiome profile between these two groups, specifically with Bifidobacterium breve, Bifidobacterium pseudocatenulatum, Bifidobacterium adolescentis, Escherichia coli, Faecalibacterium prausnitzii, and Akkermansia muciniphila. Finally, Fazlollahi et al. looked at the role of gut microbiota in egg allergic children and found a distinction in diversity of microbial flora compared to non-food allergic controls (34). While this data is important for our discovery of the end outcome of atopy, the specific human milk components on microbiome and atopy development are discussed in this review.

Human milk originates in the lactating mammary tissue. Milk lipid, lactose, and the majority of milk proteins are produced in the lactating cells (35). Human milk contains immune cells, immunoglobulins, cytokines, chemokines, growth factors, lactoferrin, oligosaccharides, enzymes (peroxidases, lysozymes), secretory components, and hormones, along with foreign food antigens, bacteria and viruses $(6,36)$. Several of these bioactive factors have been assessed in relation to development of allergies in the infant, and many of these immunologically active factors in human milk are missing in processed cow's milk and infant formulas, in which the whey to casein ratio is markedly lower than in human milk $(37,38)$. This review summarizes the current literature on human milk components that have been associated with protection against food allergy and related allergic disorders in early childhood and discusses the work relating to regulation of these levels in human milk and possible mechanisms of action.

\section{CYTOKINES, CHEMOKINES, AND GROWTH FACTORS}

Cytokines, which include chemokines, interleukins, interferons, and growth factors, are signaling molecules that function in cellular communication. Human milk is a rich source of immunostimulatory and immunoregulatory cytokines $(6,39)$. There is variation in the concentration of cytokines among mothers, and overall concentrations for several of those are relatively low in human milk, causing debate in the clinical significance of cytokine levels on health outcomes. Some of the variation in cytokine levels is thought to be due to varying maternal (microbial) exposures. Milk interleukin (IL)-10, interferon (IFN) $-\gamma(40)$ and transforming growth factor (TGF) $\beta$ (41) levels have been shown to vary depending on mothers' country of residence, and country of birth (42), and TGF $\beta$ as an example is in human milk at a biologically meaningful concentration.

TGF $\beta$ is an important regulatory cytokine involved in suppression of both Th1 and Th2 pathways, and is the molecule that has been most studied. The three isoforms of TGF $\beta$ combined make it the most prevalent cytokine in human milk, with the most abundant being $\operatorname{TGF} \beta-2(43,44)$. Immunomodulatory cytokines in murine milk, including TGF $\beta$ have been shown to influence the development and maturation of the mucosal immune system in neonatal mice and to be associated with the protection against allergic asthma (45). Some studies have confirmed that milk TGF $\beta$ is immunologically active, and involved in the induction of oral tolerance, perhaps by inducing increased production of specific $\operatorname{IgA}(46,47)$. Alternatively, TGF $\beta-2$ has been shown to induce maturation of immature intestinal epithelial cells (48). Protection induced by human milk TGF $\beta$ has especially been noted in the development of atopic dermatitis (43). This was supported in a review in 2010 by Oddy and Rosales of twelve human studies that determined that $67 \%$ of the studies showed a positive association of TGF $\beta$ 1 or TGF $\beta-2$ preventing atopic outcomes in infancy and early childhood (49). The study concluded that TGF $\beta$ is likely essential in the development of immune responses in infants and may provide protection against adverse immunological outcomes (49). Overall, however, there is conflicting data regarding the role TGF $\beta$ in the development of atopic disease in humans (41, 50-56). Most recently, a study by Morita et al. showed that lower concentration of TGF $\beta-1$ in human milk at 1 month, but not TGF $\beta$-2, may be linked to development of eczema (57). 
In another study of food allergy, the concentration of TGF $\beta-1$ in colostrum from mothers of infants with IgE-mediated cow's milk allergy was lower than from mothers of infants with nonIgE-mediated cow's milk allergy; however, the levels in healthy controls were found in between (58). The studies are summarized in Table 1. A recent study showed that human milk TGF $\beta$ was associated with increased richness, evenness and diversity of infant gut microbiome composition (61).

Emerging data regarding the role of other human milk cytokines and chemokines on allergic disease development has been variable. A summary of association between cytokines and the development of food allergy can be found in Table 2. Earlier studies using ELISA found that levels of IL-4 are lower and IL8 and CCL5 (RANTES) are higher in human milk from atopic compared to non-atopic mothers $(63,64)$, though others found that cytokine levels were largely not related to maternal atopy $(6,65)$. Various studies report low to undetectable levels of other cytokines and chemokines including IFN $\gamma$, IL-2, IL-4, IL5, IL-10, IL-12, IL-13, CCL5, CXCL8, CXCL10, and TNF- $\alpha$ and have found no association with development of atopic disease despite their involvement in immune and intestinal development $(39,50,53,55,66,67)$. Pro-inflammatory cytokines, including IL-1 $\beta$, IL-6, and IL- 8 are also found in human milk in low concentrations. IL-6, IL-8, CXCL8, and CXCL10 in human milk have been shown to be affected by factors such as gestational smoking, maternal race, and season (68) and exercise has been associated with elevated levels of IL-1 $\beta$ and IL-17 (69). There are studies showing that some of these cytokine levels in milk may impact allergic outcomes in offspring. Increased levels of IL-1 $\beta$ in human milk have been shown to be associated with protection against eczema (55). Soto-Ramirez et al. showed that IL-5 and IL-13 levels in milk, although extremely low, are risk factors for asthma at 12 months of age (67). CCL5 in milk was the strongest risk factor for development of atopic dermatitis in the study by Ochiai et al. (65). Because food allergy represents a failure in development of mucosal tolerance to foods, immune factors in human milk may have a more direct effect on development of food allergy (62). In fact, our study showed that a panel of pro-inflammatory and regulatory cytokines including IL-1 $\beta$, IL-6, IL-10, and TGF $\beta-1$ in human milk were associated with protection against CMA $(6,62)$. These cytokines promote IgA production, Th17 differentiation and microbiota-driven crosstalk between gut macrophages and ROR $\gamma \mathrm{t}^{+}$ILC-3 population (70). It is unclear whether these bioactive factors are directly related to protection or whether they are biomarkers of another protective mechanism (6).

Other growth factors have also been shown to be present in high concentrations in human milk, including vascular endothelial growth factor, hepatic growth factor, and epidermal growth factor, though the clinical importance is unknown (56, 62, 71). Most recently, a study was conducted by Munblit et al. in which 398 pregnant/lactating women in the United Kingdom, Russia, and Italy were followed prospectively to look for an association between levels of immune mediators in colostrum/mature human milk and allergic outcomes in infants during the first year of life (56). Hepatocyte growth factor (HGF) in mature human milk was protective against common cold incidence at 12 months. Other study outcomes in infants included eczema symptoms, parental-reported food allergy, and recurrent cough/wheeze at 6 and 12 months of age. Results showed higher levels of IL-13 in the colostrum and mature human milk were protective against parent reported food allergy and eczema respectively. IL-2, IL-4, IL-5, IL-10, IL-12, and IFN $\gamma$ showed no significant association with eczema, wheeze or food allergy (56).

\section{SOLUBLE CD14/TLR}

Human milk may also influence neonatal microbial recognition by modulating Toll-like receptor (TLR)-mediated responses specifically and differentially (72). Necrotizing enterocolitis has been shown to be reduced in infants who are breastfed, mediated likely via the lipopolysaccharide (LPS) receptor TLR4 preventing mucosal injury and promotion of repair (73). CD14 is the soluble component (sCD14) of the TLR4, which has a role in innate immunity. It binds to LPS from gram-negative bacteria and intestinal enterocytes. The absence of sCD14 reduces the TLR4 response to LPS. Colostrum is rich in sCD14 with levels decreasing over time whereas neonates lack CD14. Soluble CD14 levels have been found to be lower in colostrum and human milk of mothers with children who develop atopy or eczema, sensitization $(6,74)$. Later studies, however, deny an association between levels of sCD14 and development of atopy $(52,54)$. In 2015, Savilahti et al. showed that elevated sCD14 in human milk 3 months post-partum was associated with development of IgE-mediated allergic disease by 5 years of age in children who had hereditary risk of atopy, suggesting that sCD14 in milk influences the emergence of allergy in children with atopic heredity (75). This study contrasted with a study by the same group from 2005 that showed sCD14 levels were lower in colostrum of mothers with infants developing atopic symptoms and $\operatorname{IgE}$ sensitization than of those of infants with no atopy (51). Studies regarding sCD14 in human milk are summarized in Table 3. The conclusions are mixed and there does not appear to be a clear relationship between sCD14 levels in human milk and development of atopic disease.

\section{IMMUNOGLOBULIN A (IgA)}

The predominant immunoglobulin in human milk is IgA, most of which is in the form of secretory $\operatorname{IgA}(\operatorname{SIgA})$, with smaller amounts of $\operatorname{IgG}$ and $\operatorname{IgM}(6,76)$. An older study utilized human milk from a prospective birth cohort of 145 motherinfant dyads oversampled for high risk of food allergies and followed for 12-18 months for development of CMA. The study showed that high levels of human milk total (77) and cow's milk-specific IgA (78) were associated with protection against CMA, consistent with other reports $(79,80)$. While the exact function of IgA in human milk is unknown, it is thought to supplement infant IgA production, which only commences after birth $(78,81)$. Data from several studies support a role for maternal environment (geographic location, microbial pressure, exposure to farm animals and cats) in driving milk IgA levels and 
TABLE 1 | Studies pertaining to TGF $\beta$ in human milk and development of atopic disease.

\begin{tabular}{|c|c|c|c|c|c|}
\hline Study & Year & Location & Size & Duration/Age & Outcomes \\
\hline Kalliomaki et al. (43) & 1999 & Finland & $n=47$ & Up to 12 months & $\begin{array}{l}\text { Increased TGF } \beta \text { - } 1 \text { and } 2 \text { levels in colostrum } \\
\text { were associated with higher post } \\
\text { weaning-onset atopic disease }\end{array}$ \\
\hline Saarinen et al. (58) & 1999 & Finland & $n=6209$ & Up to 12.7 months & $\begin{array}{l}\text { Increased TGF } \beta \text { - } 1 \text { levels in colostrum are } \\
\text { associated with infants who develop } \\
\text { lgE-mediated cow's milk allergy versus } \\
\text { non-lgE-mediated cow's milk allergy; healthy } \\
\text { controls were found in between }\end{array}$ \\
\hline Bottcher et al. (50) & 2003 & Sweden & $n=53$ & Up to 2 years & $\begin{array}{l}\text { TGF } \beta-1 \text { and } 2 \text { levels were not significantly } \\
\text { associated with eczema, salivary lgA, or allergic } \\
\text { sensitization }\end{array}$ \\
\hline Oddy et al. (59) & 2003 & Australia & $n=243$ & Infancy & $\begin{array}{l}\text { Increased TGF } \beta-1 \text { is associated with lower risk } \\
\text { of wheeze in infancy }\end{array}$ \\
\hline Savilahti et al. (51) & 2005 & Finland & $n=4674$ & Up to age 4 years & $\begin{array}{l}\text { TGF } \beta-1 \text { and } 2 \text { levels were not significantly } \\
\text { associated with atopy development }\end{array}$ \\
\hline Snijders et al. (52) & 2006 & Netherlands & $n=315$ & $\begin{array}{l}\text { Eczema (up to } 12 \text { months), } \\
\text { Wheezing (up to } 2 \text { years), } \\
\text { Allergic sensitization (up to } 2 \\
\text { years) }\end{array}$ & $\begin{array}{l}\text { No significant association of with TGF } \beta \text { - } 1 \text { and } \\
\text { development of eczema, wheezing or allergic } \\
\text { sensitization }\end{array}$ \\
\hline Bottcher et al. (60) & 2008 & Sweden & $\begin{array}{l}n=54 \\
(\text { L. reuteri) } n=55 \text { (control) }\end{array}$ & Up to 2 yeas & $\begin{array}{l}\text { Decreased TGF } \beta \text { - } 2 \text { in colostrum is associated } \\
\text { with lower incidence of allergic sensitization } \\
\text { and a trend of protective effect on eczema } \\
\text { development }\end{array}$ \\
\hline Kuitunen et al. (53) & 2012 & Finland & $\begin{array}{l}n=364 \\
(\text { colostrum) } n=321(\mathrm{BM})\end{array}$ & At 2 years of age & $\begin{array}{l}\text { Increased TGF } \beta \text { - } 2 \text { is associated with higher risk } \\
\text { of allergic disease and eczema }\end{array}$ \\
\hline Ismail et al. (54) & 2013 & Australia & $n=79$ & Up to 12 months & $\begin{array}{l}\text { TGF } \beta \text { - } 1 \text { level was not significantly associated } \\
\text { with eczema or allergic sensitization }\end{array}$ \\
\hline Orivuori et al. (41) & 2014 & $\begin{array}{l}\text { Finland, France, } \\
\text { Germany and } \\
\text { Switzerland }\end{array}$ & $n=610$ & $\begin{array}{l}\text { Eczema (up to } 4 \text { years), } \\
\text { asthma (up to } 6 \text { years), } \\
\text { allergic sensitization (up to } 6 \\
\text { years) }\end{array}$ & $\begin{array}{l}\text { TGF } \beta \text { - } 1 \text { level was not significantly associated } \\
\text { with eczema, asthma, or allergic sensitization }\end{array}$ \\
\hline Jepsen et al. (55) & 2016 & Denmark & $n=223$ & Up to 3 years & $\begin{array}{l}\text { TGF } \beta-1 \text { level was not significantly associated } \\
\text { with recurrent eczema or wheeze }\end{array}$ \\
\hline Munblit et al. (56) & 2017 & $\begin{array}{l}\text { United Kingdom, } \\
\text { Russia and Italy }\end{array}$ & $n=398$ & Up to 6 months & $\begin{array}{l}\text { Increased TGF } \beta \text { - } 2 \text { is associated with higher risk } \\
\text { of eczema }\end{array}$ \\
\hline Morita et al. (57) & 2018 & Japan & $\begin{array}{l}n=43 \\
\text { (eczema) } n=53 \text { (control) }\end{array}$ & Up to 6 months & $\begin{array}{l}\text { Lower TGF } \beta \text { - } 1 \text { ratio (1-month milk/colostrum) is } \\
\text { associated with higher risk of eczema }\end{array}$ \\
\hline
\end{tabular}

specificity $(40,41,82)$. Some studies have shown a link between high IgA levels and protection for the development of atopic dermatitis $(41,51)$ while other studies show no link between sIgA and development of other atopic diseases $(41,50,54)$.

Mucosal IgAs are produced by plasma cells in the gut lamina propria and are transported across epithelial cells by the polymeric immunoglobulin receptor (pIgR) (83). Human milk IgA is produced by mammary gland $\mathrm{B}$ cells that have migrated from the mother's intestine via the "enteromammary link" $(84,85)$, as shown in animal studies (86-89). This is controlled by the mucosal vascular addressin MadCAM-1 or mucosaassociated epithelial chemokine CCL28, which interacts with the gut homing receptor $\alpha_{4} \beta_{7}$ integrin (90) and mucosa-associated CCR10 (91). Consistent with this, in a rabbit model either oral or inhaled RSV resulted in RSV-IgA production in milk, bronchial and enteral secretions, whereas systemic immunization did not (92). Studies in humans (93) showed that oral immunization in women resulted in an increase in plasma cells in milk, but not in saliva or serum, (85). This forms the hypothesis that human milk IgA reflects the antigenic exposure of the mother's gut to dietary proteins as well. Using the cohort mentioned above, it was shown that a strict maternal diet restricting cow's milk was associated with lower levels of sIgA levels in human milk than cow's milk-containing diet (78). This implies that the antigenic stimulation encountered by the maternal gut directs the antibody specificity of human milk (85). In order to further understand the regulation of IgA in milk, epitope-specific binding of IgA in milk was compared to paired maternal serum samples (85). This revealed that IgA in human milk had partially different epitope specificity to cow's milk antigens than IgA in serum, suggesting different pools of antibody-producing lymphocytes controlling serum and human milk antibodies, respectively, and therefore supporting evidence for enteromammary milk. In summary, IgA levels expressed in human milk are influenced by many maternal factors, including diet, location, exposures, microbiota, and likely plays a protective role against development of cow's milk allergy. 
TABLE 2 | Summary of association between cytokines and the development of food sensitization/allergy.

\begin{tabular}{|c|c|c|c|c|c|c|}
\hline Study & Year & Location & Size & Duration/Age & Cytokines assessed & $\begin{array}{l}\text { Food allergy } \\
\text { development }\end{array}$ \\
\hline Bottcher et al. (50) & 2003 & Sweden & $n=53$ & Up to 2 years & $\begin{array}{l}\text { IL-4, IL-5, IL-6, IL-8, IL-10, IL-13, IL-16, } \\
\text { IFN- } \gamma \text {, TGF } \beta-1, \text { TGF } \beta-2 \text {, RANTES, eotaxin }\end{array}$ & No significant association \\
\hline Snijders et al. (52) & 2006 & Netherlands & $n=315$ & Up to 2 years & $\begin{array}{l}\text { IL-12 or TGF } \beta-1 \\
\text { (IL-10 undetectable) }\end{array}$ & $\begin{array}{l}\text { No significant } \\
\text { association }\end{array}$ \\
\hline Kuitunen et al. (53) & 2012 & Finland & $\begin{array}{l}n=364 \\
\text { (colostrum) } \\
n=321 \\
(3 \text { month HM) }\end{array}$ & At 2 years of age & IL-10, TGF $\beta-1$ & $\begin{array}{l}\text { No significant } \\
\text { association }\end{array}$ \\
\hline Järvinen et al. (62) & 2015 & Finland & $n=145$ & Up to 2 years & $\begin{array}{l}\text { IL-1 } \alpha \text {, IL-1 } \beta, \text { IL-6, IL-10 } \\
\text { PDGF-BB, CCL27, VEGF, TSLP, CCL11, } \\
\text { CXCL10, and CXCL11, CCL22, TGF } \beta-1 \text {, } \\
\text { (TNF-a and -b, CCL1, CCL17, IL-31, } \\
\text { eotaxin 3, CXCL9, IL-5, GM-CSF, and } \\
\text { IL-12p70 undetectable) }\end{array}$ & $\begin{array}{l}\text { IL-1 } \beta \text {, IL-6, IL-10, and } \\
\text { TGF } \beta-1 \text { in human milk } \\
\text { showed association with } \\
\text { cow's milk tolerance }\end{array}$ \\
\hline
\end{tabular}

HM, Human milk.

TABLE 3 | Studies pertaining to SCD14 in human milk and development of atopic disease.

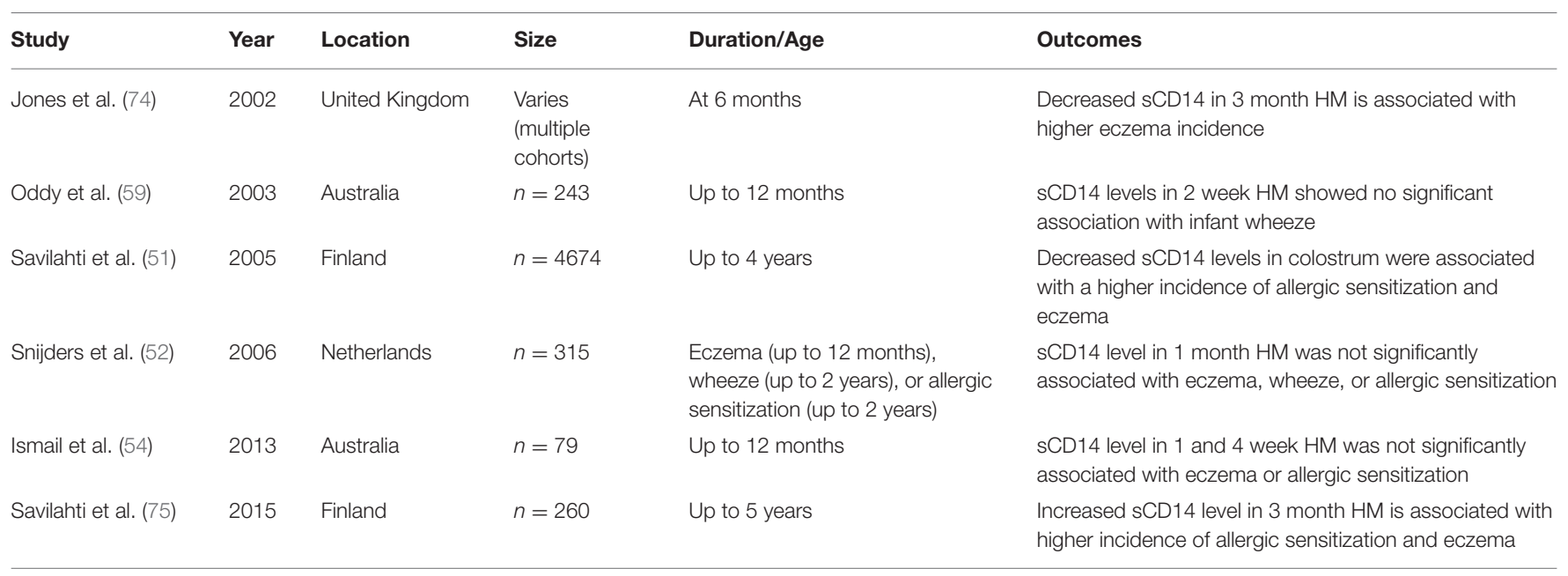

HM, Human milk.

\section{MICROBIOME}

Infant microbiome composition is influenced by breastfeeding $(94,95)$. Human milk can modify the infant microbiome directly through seeding from the maternal microbiome and through the other effects of human milk. Diversity of the infant gut microbiome develops in the first 2 years of life and Bifidobacteria dominate throughout the first year (96). Recent studies have shown that host genetics, prenatal environment and delivery mode can shape the newborn microbiome at birth [reviewed in (97)]. Following this, postnatal factors, such as antibiotic treatment, diet and environmental exposure, further modulate the development of the infant's microbiome and immune system.
Living on farms, avoiding antibiotics, vaginal delivery, and other environmental factors leading to greater diversity in the microbiome have been associated with a major reduction in the risk of atopic diseases $(98,99)$. Several large studies have confirmed the role of breastfeeding in determining the gut microbiome. Initially there is lower microbiome diversity with breastfeeding, as human milk selects for a highly adapted intestinal microbiota, and when breastfeeding is ceased and complementary feeds start, Lactobacilli, Bifidobacteria, and Enterobacteriaceae are replaced with a microbiota dominated by Clostridium and Bacteroides species(100-103). The WHEALS birth cohort confirmed that together with the mode of delivery, breastfeeding is one of the most important factors impacting 
infant microbiome (95). Interestingly, however, only $12-14 \%$ of variability was explained by maternal mode of delivery, exposure to pets, demographics and breastfeeding. This may be partly due to the fact that the human milk biologically active components such as IgA and HMOs, which can modulate microbial composition and function, were not specifically considered. Their concentrations vary between mothers, and this variation is not captured in a coarse definition of breastfeeding.

Several culture-dependent and-independent studies have revealed that colostrum and human milk contain a variety of bacterial communities that colonize the infant's gut. The initial studies demonstrated predominance of staphylococci, lactobacilli, streptococci and propionibacterium, and closely related gram-positive bacteria (104). Culture-independent molecular techniques, especially those utilizing 16S rRNA sequencing have confirmed a similar diversity of bacteria, but also presence of several others including Gram-negative bacteria (6, 105-109). Milk bacterial communities vary between mothers but are relatively stable within individuals (106). Human milk microbiota has been shown to act as a source of bacterial species that colonize the infant gut (110), to be but different from skin suggesting an endogenous route for human milk colonization $(105,111)$. The amount of bacteria ingested by an infant per $800 \mathrm{~mL}$ of milk consumed daily is estimated at $1 \times 10^{5}-1 \times 10^{7}$, though this is likely an underestimation (112). Recently, it was shown that human milk provides a source of about one-fourth of infant gut microbiota (113).

\section{HUMAN MILK OLIGOSACCHARIDES}

Human milk oligosaccharides (HMOs) provide the main substrate for an infant's gut microbiota during exclusive breastfeeding, particularly promoting bifidobacteria and Bacteroides (114-116). Some HMOs have anti-inflammatory properties, and support maturation of the gut mucosal immune system (117). Some also have an inhibitory effect on intestinal cell growth (118), and some bind to dendritic cells through the lectin receptor DC-SIGN (119) inhibiting HIV transfer to T-cells. These oligosaccharides are not digestible by the infant and are extensions of lactose generated by the action of a series of glycosyltransferases. For fucose, two fucosyltransferases FUT2 (secretor gene) and FUT3 (Lewis gene) are implicated. Depending on the Lewis blood group and secretor status, different enzymes are available for the synthesis of HMOs. As a result, human milk from different mothers have significant variations in qualitative and quantitative composition of HMOs. HMO composition is relatively stable during the course of lactation, although it is not known whether minor daily variations are due to the mother's diet (120). This heterogeneity implies that some breast-fed infants are not being exposed to certain structures. Non-secretor mothers, lacking a functional FUT2 enzyme (FUT2-/-), represent $15-25 \%$ of mothers depending on their ethnic background $(121,122)$, and their milk is missing all alpha-2 linked fucose oligosaccharides (21). Infants fed by non-secretor mothers are delayed in establishment of bifidobacteria-laden microbiota
(123). Differences in HMOs have also been associated with susceptibility to infectious gastroenteritis $(124,125)$ and HIV (126-128). In our previous studies, certain HMO profiles were associated with protection against cow's milk allergy (129). Infants who received human milk with low Lacto-Nfucopentaose (LNFP) III concentrations were more likely to become affected with CMA when compared to those receiving milk with high levels ( $p=0.00036$, odds ratio 6.7, 95\% CI 2.022). Two other studies have assessed the association between HMO and atopic diseases. A study that followed 20 infants for the first 18 months for development of FA, and measured HMOs using HPLC was powered to only find major effects, and indeed did not find a significant difference in HMOs between mothers of allergic and non-allergic children (130). In a second study, infants fed by non-secretor mothers had delayed development of bifidobacteria-laden microbiota (123) and if also born via c-section had a higher risk to manifest IgE-associated eczema (21). However, development of food allergy or composition of individual HMOs were not assessed. These data support the role of HMOs in protection against CMA, possibly through their effect on infant gut microbiome. Most recently, the Canadian Healthy Infant Longitudinal Development (CHILD) study, compared HMO profiles with food sensitization at 1 year of age (131). The study found that lower risk for food sensitization was associated with higher concentrations of fucosyl-disialyllacto$\mathrm{N}$-hexaose (FDSLNH), lacto-N-fucopentaose II (LNFPII), lacto-N-neotetraose (LNnT), lacto-N-fucopentaose I (LNFPI), sialyllacto-N-tetraose c (LSTc), and fucosyllacto-N-hexaose (FLNH), and relatively lower concentrations of lacto-N-hexaose $(\mathrm{LNH})$, lacto-N-tetraose (LNT), 2' -fucosyllactose $\left(2^{\prime} \mathrm{FL}\right)$, and disialyllacto-N-hexaose (DSLNH). Further investigation into HMO composition is necessary to better understand the role of HMOs in pathophysiology and possibly future therapeutics for prevention of atopic disease.

\section{FATTY ACIDS}

Milk lipids are principal macronutrients in human milk and studies have shown that milk from atopic mothers varies in fatty acid content. Polyunsaturated fatty acids (PUFAs), more specifically the omega-3 ( $\omega-3)$ fatty acids, e.g., docosahexaenoic (DHA) and eicosapentaenoic (EPA), have been recently shown to have anti-inflammatory effects in chronic inflammatory diseases, such as asthma (132). On a maternal fish oil supplementation trial, omega-3 PUFA levels were positively associated with IgA and sCD14 levels, suggesting a relationship between fatty acid status and mucosal immune function (133). Another study has shown that atopic mothers' milk has lower levels of n-3 longchain PUFA at 1 month of lactation than non-atopic mothers (134). Overall, the studies examining the fatty acid profile in human milk as a risk factor for subsequent atopic disease have been mixed, though generally found that n-3 PUFAs in human milk possibly protect against atopic diseases (134-139). The conflicting findings may be due to the complex interactions between different fatty acids types and the divergent functions on immune system based on the dose $(6,140)$. 
More recently, the short-chain fatty acids (SCFAs), including acetate, butyrate and propionate, have been demonstrated as possibly important mediators of allergic inflammation. Inflammation is likely a by-product of the metabolic activity of gut microbiota given that SCFAs are altered in children who are or become overweight or atopic (141). SCFAs are the first metabolites produced by the gut microbiota of newborns, with synthesis increasing rapidly after birth (142). As commensal microbiome has been shown to be protective against food sensitization in animal models (26), this may be due to the SCFAs produced by these commensal bacteria. In mice, experimental data has shown that increased SCFAs, especially acetate and butyrate, may prevent development of food allergy by way of promoting the tolerogenic effect of $\mathrm{CD}_{103}{ }^{+}$dendritic cells (143). Initial studies have shown that in term infants, total gut SCFA levels are elevated in formula-fed vs. breastfed infants, however acetate levels in particular are highest with exclusive breastfeeding $(141,144)$. There are no published studies of SCFA levels in human milk.

\section{HUMAN MILK CELLS}

A variety of other factors have yet to be better investigated in terms of the impact on the development of inflammation and immunity. Extremely interesting is recent data suggesting that up to $6 \%$ of cells in human milk are stem cells, and mesenchymal stem cells isolated from human milk are potentially reprogrammable to many types of tissue $(145,146)$. These cells may play a role in development of immune cells, including regulatory $\mathrm{T}$ cell, which may suppress antimaternal immunity and lead to microchimerism that induce intestinal tissue repair and immune protection (146). Colostrum is specifically also rich in leukocytes, with breastfed infants being exposed to as much as $10^{10}$ maternal leukocytes per day, and the role of this exposure in immune development in infants is not yet clear (44). One study of 61 mothers and infants did show that macrophage proportion was significantly smaller in the milk of mothers who had infants with cow's milk allergy compared to mothers who had healthy infants, whereas neutrophil, eosinophil or lymphocyte abundant milk noted significantly more often being received by infants with cow's milk allergy (147). There is still much to learn about the effect of these factors in prevention of allergic disease.

\section{DIETARY ANTIGENS}

Maternal dietary antigens, including ovalbumin, $\beta$-lactoglobulin, gliadin and peanut, have been detected in human milk generally in quantities varying from undetectable levels to $430 \mathrm{ng} / \mathrm{ml}$

\section{REFERENCES}

1. Victora CG, Bahl R, Barros AJ, Franca GV, Horton S, Krasevec J, et al. Breastfeeding in the 21st century: epidemiology, mechanisms, and lifelong effect. Lancet (2016) 387:475-90. doi: 10.1016/S0140-6736(15)01024-7

2. Bachrach VR, Schwarz E, Bachrach L. Breastfeeding and the risk of hospitalization for respiratory disease in infancy: a meta-analysis. Arch Pediatr Adolesc Med. (2003) 157:237-43. doi: 10.1001/archpedi.157.3.237
(148-155). Although their role in inducing symptoms in already sensitized infants has been shown (150), and the ingestion of egg has been associated with immune markers in infants (155), their role in initial sensitization or tolerance development in humans is still debated.

\section{CONCLUSIONS}

The immunomodulatory composition of human milk is surprisingly poorly characterized and varies between mothers. The coarse definition of breastfeeding used in epidemiologic studies does not take into consideration the variability in the numerous immunologically active factors in human milk, which may lead to conflicting data regarding the impact of breastfeeding on immune development and downstream implications on development of prevention of allergic disease. Whereas one mother's milk may be rich is immunoprotective factors, another mother's milk may not; however epidemiologic studies do not differentiate between these two very different infant dietary (and microbial) exposures. In addition, randomized controlled trials, with assignments to either breastfeed or not, are lacking, and definitions of breastfeeding and allergic outcomes vary. Unfortunately, most studies have been underpowered for food allergies or not assessed at all due to methodologic problems of making the firm diagnosis.

The studies above suggest that, upon a closer look, the milieu of biomarkers in human milk varies between mothers and the composition may play a function in progression to or prevention against atopy. The impact of human milk biologically active components can be direct or perhaps due to modulation of intestinal microbial composition and function. Most importantly, the factors do not act in isolation, and the study into the impact of a combination or networks of immune factors in human milk on infant microbiome and immune development is still "in its infancy." Better elucidation of the role of these factors could lead to early targets for treatment and prevention of allergic disease. Further and larger wellcharacterized studies using prospective cohort data would be extremely helpful in determining the most important factors that likely play a role in development of atopic diseases. The above studies shed a guiding light for future areas of research.

\section{AUTHOR CONTRIBUTIONS}

PR wrote sections including introduction, cytokines, soluble as CD14/TLR, fatty acids, human milk cells, and conclusions. AS and $\mathrm{KJ}$ mentors and editors, wrote abstract and sections on HMOs, IgA, and microbiome.
3. Kramer MS, Kakuma R. Optimal duration of exclusive breastfeeding. Cochrane Database Syst Rev. (2012) 8:CD003517. doi: 10.1002/14651858.CD003517.pub2

4. Kramer MS. Does breast feeding help protect against atopic disease? Biology, methodology, and a golden jubilee of controversy. J Pediatr. (1988) 112:18190. doi: 10.1016/S0022-3476(88)80054-4

5. Kramer MS, Matush L, Vanilovich I, Platt R, Bogdanovich N, Sevkovskaya $Z$, et al. Effect of prolonged and exclusive breast feeding on risk 
of allergy and asthma: cluster randomised trial. BMJ (2007) 335:815. doi: 10.1136/bmj.39304.464016.AE

6. Järvinen KM, Bergmann KE, Bergmann R. Breast-Always Best? In: Allergy, Immunity and Tolerance in Early Childhood: The First Steps of the Atopic. (New York, NY: Elsevier) (2015), p. 235-260.

7. van Odijk J, Kull I, Borres MP, Brandtzaeg P, Edberg U, Hanson LA, et al. Breastfeeding and allergic disease: a multidisciplinary review of the literature (1966-2001) on the mode of early feeding in infancy and its impact on later atopic manifestations. Allergy (2003) 58:833-43. doi: 10.1034/j.1398-9995.2003.00264.x

8. Muraro A, Dreborg S, Halken S, Host A, Niggemann B, Aalberse R, et al. Dietary prevention of allergic diseases in infants and small children. Part I: immunologic background and criteria for hypoallergenicity Pediatric allergy and immunology. Eur Soc Pediatr Allergy Immunol. (2004) 15:103-11. doi: 10.1046/j.1399-3038.2003.00129.x

9. Greer FR, Sicherer SH, Burks AW, American Academy of Pediatrics Committee on Nutrition, American Academy of Pediatrics Section on Allergy and Immunology. Effects of early nutritional interventions on the development of atopic disease in infants and children: the role of maternal dietary restriction, breastfeeding, timing of introduction of complementary foods, and hydrolyzed formulas. Pediatrics (2008) 121:183-91. doi: 10.1542/peds.2007-3022.

10. Lodge CJ, Tan DJ, Lau MX, Dai X, Tham R, Lowe AJ, et al. Breastfeeding and asthma and allergies: a systematic review and meta-analysis. Acta Paediatr. (2015) 104:38-53. doi: 10.1111/apa.13132

11. Fleischer DM, Spergel JM, Assaad AH, Pongracic JA. Primary prevention of allergic disease through nutritional interventions. Journal Allergy Clin. Immunol Pract. (2013) 1, 29-36. doi: 10.1016/j.jaip.2012.09.003

12. Gdalevich M, Mimouni D, David M, Mimouni M. Breast-feeding and the onset of atopic dermatitis in childhood: a systematic review and metaanalysis of prospective studies. J Am Acad Dermatol. (2001) 45:520-7. doi: $10.1067 / \mathrm{mjd} .2001 .114741$

13. Gdalevich M, Mimouni D, Mimouni M. Breast-feeding and the risk of bronchial asthma in childhood: a systematic review with meta-analysis of prospective studies. J Pediatr. (2001) 139:261-6. doi: $10.1067 / \mathrm{mpd} .2001 .117006$

14. Kull I, Bohme M, Wahlgren CF, Nordvall L, Pershagen G, Wickman M. Breast-feeding reduces the risk for childhood eczema. J Allergy Clin Immunol. (2005) 116:657-61. doi: 10.1016/j.jaci.2005.04.028

15. Lowe AJ, Carlin JB, Bennett CM, Abramson MJ, Hosking CS, Hill DJ, et al. Atopic disease and breast-feeding-cause or consequence? J Allergy Clin Immunol. (2006) 117:682-7. doi: 10.1016/j.jaci.2005.10.027

16. Giwercman C, Halkjaer LB, Jensen SM, Bonnelykke K, Lauritzen L, Bisgaard H. Increased risk of eczema but reduced risk of early wheezy disorder from exclusive breast-feeding in high-risk infants. J Allergy Clin Immunol. (2010) 125:866-71. doi: 10.1016/j.jaci.2010.01.026

17. Kramer MS, Chalmers B, Hodnett ED, Sevkovskaya Z, Dzikovich I, Shapiro $\mathrm{S}$, et al. Promotion of Breastfeeding Intervention Trial (PROBIT): a randomized trial in the Republic of Belarus. JAMA (2001) 285:413-20. doi: 10.1001/jama.285.4.413

18. Katz Y, Rajuan N, Goldberg MR, Eisenberg E, Heyman E, Cohen A, et al. Early exposure to cow's milk protein is protective against IgE-mediated cow's milk protein allergy. J Allergy Clin Immunol. (2010) 126:77-82 e71. doi: 10.1016/j.jaci.2010.04.020

19. Flohr C, Nagel G, Weinmayr G, Kleiner A, Strachan DP, Williams $\mathrm{HC}$, et al. Lack of evidence for a protective effect of prolonged breastfeeding on childhood eczema: lessons from the International Study of Asthma and Allergies in Childhood (ISAAC) Phase Two. Br J Dermatol. (2011) 165:1280-9. doi: 10.1111/j.1365-2133.2011. 10588.x

20. Sakihara T, Sugiura S, Ito K. The ingestion of cow's milk formula in the first 3 months of life prevents the development of cow's milk allergy. Asia Pac Allergy (2016) 6:207-12. doi: 10.5415/apallergy.2016.6.4.207

21. Sprenger N, Odenwald H, Kukkonen AK, Kuitunen M, Savilahti E, Kunz C. FUT2-dependent breast milk oligosaccharides and allergy at 2 and 5 years of age in infants with high hereditary allergy risk. Eur J Nutr. 56:1293-1301 (2016). doi: 10.1007/s00394-016-1180-6
22. Mackie RI, Sghir A, Gaskins HR. Developmental microbial ecology of the neonatal gastrointestinal tract. Am J Clin Nutr (1999) 69:1035S-1045S. doi: $10.1093 /$ ajcn/69.5.1035s

23. Macfarlane GT, Macfarlane LE. Acquisition, evolution and maintenance of the normal gut microbiota. Dig Dis. (2009) 27(Suppl. 1):90-8. doi: $10.1159 / 000268127$

24. Morelli L. Postnatal development of intestinal microflora as influenced by infant nutrition. J Nutr. (2008) 138:1791S-5S. doi: 10.1093/jn/138.9.1791S

25. Young VB. The intestinal microbiota in health and disease. Curr Opin Gastroenterol. (2012) 28:63-9. doi: 10.1097/MOG.0b013e32834d61e9

26. Stefka AT, Feehley T, Tripathi P, Qiu J, McCoy K, Mazmanian SK, et al. Commensal bacteria protect against food allergen sensitization. Proc Natl Acad Sci USA. (2014) 111:13145-50. doi: 10.1073/pnas.1412008111

27. Abrahamsson TR, Jakobsson HE, Andersson AF, Bjorksten B, Engstrand L, Jenmalm MC. Low diversity of the gut microbiota in infants with atopic eczema. J Allergy Clin Immunol. (2012) 129:434-40, 440 e431-32. doi: 10.1016/j.jaci.2011.10.025

28. Kalliomaki M, Kirjavainen P, Eerola E, Kero P, Salminen S, Isolauri E. Distinct patterns of neonatal gut microflora in infants in whom atopy was and was not developing. J Allergy Clin Immunol. (2001) 107:129-34. doi: $10.1067 /$ mai.2001.111237

29. Ismail IH, Oppedisano F, Joseph SJ, Boyle RJ, Licciardi PV, Robins-Browne $\mathrm{RM}$, et al. Reduced gut microbial diversity in early life is associated with later development of eczema but not atopy in high-risk infants. Pediatr Allergy Immunol. (2012) 23:674-81. doi: 10.1111/j.1399-3038.2012.01328.x

30. Ling Z, Li Z, Liu X, Cheng Y, Luo Y, Tong X, et al. Altered fecal microbiota composition associated with food allergy in infants. Appl Environ Microbiol. (2014) 80:2546-54. doi: 10.1128/AEM.00003-14

31. Azad MB, Konya T, Guttman DS, Field CJ, Sears MR, HayGlass KT, et al. Infant gut microbiota and food sensitization: associations in the first year of life. Clin Exp Allergy (2015) 45:632-43. doi: 10.1111/cea.12487

32. Kourosh A, Luna RA, Balderas M, Nance C, Anagnostou A, Devaraj S, et al. Fecal microbiome signatures are different in food-allergic children compared to siblings and healthy children. Pediatr Allergy Immunol. (2018). doi: 10.1111/pai.12904. [Epub ahead of print].

33. Fieten KB, Totte JEE, Levin E, Reyman M, Meijer Y, Knulst A, et al. Fecal microbiome and food allergy in pediatric atopic dermatitis: a cross-sectional pilot study. Int Arch Allergy Immunol. (2018) 175:77-84. doi: $10.1159 / 000484897$

34. Fazlollahi M, Chun Y, Grishin A, Wood RA, Burks AW, Dawson P, et al. Early-life gut microbiome and egg allergy. Allergy (2018) 73:1515-24. doi: $10.1111 /$ all.13389

35. Gao X, McMahon RJ, Woo JG, Davidson BS, Morrow AL, Zhang Q. Temporal changes in milk proteomes reveal developing milk functions. $J$ Proteome Res. (2012) 11:3897-907. doi: 10.1021/pr3004002

36. Andreas NJ, Kampmann B, Mehring Le-Doare K. Human breast milk: a review on its composition and bioactivity. Early Hum Dev. (2015) 91:629-35. doi: 10.1016/j.earlhumdev.2015.08.013

37. Oddy WH. The impact of breastmilk on infant and child health. Breastfeed Rev. (2002) 10:5-18.

38. Lonnerdal B. Nutritional and physiologic significance of human milk proteins. Am J Clin Nutr. (2003) 77:1537S-1543S. doi: 10.1093/ajcn/77.6.1537S

39. Agarwal S, Karmaus W, Davis S, Gangur V. Immune markers in breast milk and fetal and maternal body fluids: a systematic review of perinatal concentrations. J Hum Lact. (2011) 27:171-86. doi: $10.1177 / 0890334410395761$

40. Tomicic S, Johansson G, Voor T, Bjorksten B, Bottcher MF, Jenmalm MC. Breast milk cytokine and IgA composition differ in Estonian and Swedish mothers-relationship to microbial pressure and infant allergy. Pediatr Res. (2010) 68:330-4. doi: 10.1203/PDR.0b013e3181ee049d

41. Orivuori L, Loss G, Roduit C, Dalphin JC, Depner M, Genuneit J, et al. Soluble immunoglobulin A in breast milk is inversely associated with atopic dermatitis at early age: the PASTURE cohort study. Clin Exp Allergy (2014) 44:102-12. doi: 10.1111/cea.12199

42. Amoudruz P, Holmlund U, Schollin J, Sverremark-Ekstrom E, Montgomery SM. Maternal country of birth and previous pregnancies are associated 
with breast milk characteristics. Pediatr Allergy Immunol. (2009) 20:19-29. doi: 10.1111/j.1399-3038.2008.00754.x

43. Kalliomaki M, Ouwehand A, Arvilommi H, Kero P, Isolauri E. Transforming growth factor-beta in breast milk: a potential regulator of atopic disease at an early age. J Allergy Clin Immunol. (1999) 104:1251-7. doi: 10.1016/S0091-6749(99)70021-7

44. Ballard O, Morrow AL. Human milk composition: nutrients and bioactive factors. Pediatr Clin North Am. (2013) 60:49-74. doi: $10.1016 /$ j.pcl.2012.10.002

45. Verhasselt V, Milcent V, Cazareth J, Kanda A, Fleury S, Dombrowicz D, et al. Breast milk-mediated transfer of an antigen induces tolerance and protection from allergic asthma. Nat Med. (2008) 14:170-5. doi: 10.1038/nm1718

46. Ogawa J, Sasahara A, Yoshida T, Sira MM, Futatani T, Kanegane H, et al. Role of transforming growth factor-beta in breast milk for initiation of IgA production in newborn infants. Early Hum Dev. (2004) 77:67-75. doi: 10.1016/j.earlhumdev.2004.01.005

47. Ando T, Hatsushika K, Wako M, Ohba T, Koyama K, Ohnuma Y, et al. Orally administered TGF-beta is biologically active in the intestinal mucosa and enhances oral tolerance. J Allergy Clin Immunol. (2007) 120:916-23. doi: 10.1016/j.jaci.2007.05.023

48. Rautava S, Lu L, Nanthakumar NN, Dubert-Ferrandon A, Walker WA. TGF-beta2 induces maturation of immature human intestinal epithelial cells and inhibits inflammatory cytokine responses induced via the NF-kappaB pathway. J Pediatr Gastroenterol Nutr. (2012) 54:630-8. doi: 10.1097/MPG.0b013e31823e7c29

49. Oddy WH, Rosales F. A systematic review of the importance of milk TGF-beta on immunological outcomes in the infant and young child. Pediatr Allergy Immunol. (2010) 21(1 Pt.1):47-59. doi: 10.1111/j.1399-3038.2009.00913.x

50. Bottcher MF, Jenmalm MC, Bjorksten B. Cytokine, chemokine and secretory IgA levels in human milk in relation to atopic disease and IgA production in infants. Pediatr Allergy Immunol. (2003) 14:35-41. doi: 10.1034/j.1399-3038.2003.02120.x

51. Savilahti E, Siltanen M, Kajosaari M, Vaarala O, Saarinen KM. IgA antibodies, TGF- $\beta 1$ and $-\beta 2$, and soluble CD14 in the colostrum and development of atopy by age 4. Pediatr Res. (2005) 58:1300-5. doi: 10.1203/01.pdr.0000183784.87452.c6

52. Snijders BE, Damoiseaux JG, Penders J, Kummeling I, Stelma FF, van Ree $\mathrm{R}$, et al. Cytokines and soluble CD14 in breast milk in relation with atopic manifestations in mother and infant (KOALA Study). Clin Exp Allergy (2006) 36:1609-15. doi: 10.1111/j.1365-2222.2006.02613.x

53. Kuitunen M, Kukkonen AK, Savilahti E. Impact of maternal allergy and use of probiotics during pregnancy on breast milk cytokines and food antibodies and development of allergy in children until 5 years. Int Arch Allergy Immunol. (2012) 159:162-70. doi: 10.1159/000336157

54. Ismail IH, Licciardi PV, Oppedisano F, Boyle RJ, Tang ML. Relationship between breast milk sCD14, TGF-betal and total IgA in the first month and development of eczema during infancy. Pediatr Allergy Immunol. (2013) 24:352-60. doi: 10.1111/pai.12075

55. Jepsen AA, Chawes BL, Carson CG, Schoos AM, Thysen AH, Waage J, et al. High breast milk IL-1beta level is associated with reduced risk of childhood eczema. Clin Exp Allergy (2016) 46:1344-54. doi: 10.1111/cea.12770

56. Munblit D, Treneva M, Peroni DG, Colicino S, Chow LY, Dissanayeke $\mathrm{S}$, et al. Immune components in human milk are associated with early infant immunological health outcomes: a prospective three-country analysis. Nutrients (2017) 9:E532. doi: 10.3390/nu9060532

57. Morita Y, Campos-Alberto E, Yamaide F, Nakano T, Ohnisi H, Kawamoto $\mathrm{M}$, et al. TGF-beta concentration in breast milk is associated with the development of eczema in infants. Front Pediatr. (2018) 6:162. doi: 10.3389/fped.2018.00162

58. Saarinen KM, Vaarala O, Klemetti P, Savilahti E. Transforming growth factor-betal in mothers' colostrum and immune responses to cows' milk proteins in infants with cows' milk allergy. J Allergy Clin Immunol. (1999) 104:1093-8. doi: 10.1016/S0091-6749(99)70094-1

59. Oddy WH, Halonen M, Martinez FD, Lohman IC, Stern DA, Kurzius-Spencer $\mathrm{M}$, et al. TGF-beta in human milk is associated with wheeze in infancy. J Allergy Clin Immunol. (2003) 112:723-8. doi: 10.1016/S0091-6749(03)01941-9
60. Bottcher MF, Abrahamsson TR, Fredriksson M, Jakobsson T, Bjorksten B. Low breast milk TGF-beta2 is induced by Lactobacillus reuteri supplementation and associates with reduced risk of sensitization during infancy. Pediatr Allergy Immunol. (2008) 19:497-504. doi: 10.1111/j.1399-3038.2007.00687.x

61. Sitarik AR, Bobbitt KR, Havstad SL, Fujimura KE, Levin AM, Zoratti EM, et al. Breast milk transforming growth factor beta is associated with neonatal gut microbial composition. J Pediatr Gastroenterol Nutr. (2017) 65:e60-e67. doi: 10.1097/MPG.0000000000001585

62. Jarvinen KM, Suarez-Farinas M, Savilahti E, Sampson HA, Berin MC. Immune factors in breast milk related to infant milk allergy are independent of maternal atopy. J Allergy Clin Immunol (2015) 135:1390-3 e1391-1396. doi: 10.1016/j.jaci.2014.10.051

63. Bottcher MF, Jenmalm MC, Bjorksten B, Garofalo RP. Chemoattractant factors in breast milk from allergic and nonallergic mothers. Pediatr Res. (2000) 47:592-7. doi: 10.1203/00006450-200005000-00006

64. Bottcher MF, Jenmalm MC, Garofalo RP, Bjorksten B. Cytokines in breast milk from allergic and nonallergic mothers. Pediatr Res. (2000) 47:157-62. doi: 10.1203/00006450-200001000-00026

65. Ochiai S, Shimojo N, Morita Y, Tomiita M, Arima T, Inoue Y, et al. Cytokine biomarker candidates in breast milk associated with the development of atopic dermatitis in 6-month-old infants. Int Arch Allergy Immunol. (2013) 160:401-8. doi: 10.1159/000342995

66. Ustundag B, Yilmaz E, Dogan Y, Akarsu S, Canatan H, Halifeoglu I, et al. Levels of cytokines (IL-1beta, IL-2, IL-6, IL-8, TNF-alpha) and trace elements $(\mathrm{Zn}, \mathrm{Cu})$ in breast milk from mothers of preterm and term infants. Mediators Inflamm. (2005) 2005:331-6. doi: 10.1155/MI.2005.331

67. Soto-Ramirez N, Karmaus W, Yousefi M, Zhang H, Liu J, Gangur V. Maternal immune markers in serum during gestation and in breast milk and the risk of asthma-like symptoms at ages 6 and 12 months: a longitudinal study. Allergy Asthma Clin Immunol. (2012) 8:11. doi: 10.1186/1710-1492-8-11

68. Burch J, Karmaus W, Gangur V, Soto-Ramirez N, Yousefi M, Goetzl LM. Preand perinatal characteristics and breast milk immune markers. Pediatr Res. (2013) 74:615-21. doi: 10.1038/pr.2013.141

69. Groer MW, Shelton MM. Exercise is associated with elevated proinflammatory cytokines in human milk. $J$ Obstet Gynecol Neonatal Nurs. (2009) 38:35-41. doi: 10.1111/j.1552-6909.2008.00303.x

70. Mortha A, Chudnovskiy A, Hashimoto D, Bogunovic M, Spencer SP, Belkaid Y, et al. Microbiota-dependent crosstalk between macrophages and ILC3 promotes intestinal homeostasis. Science (2014) 343:1249288. doi: $10.1126 /$ science. 1249288

71. Kobata R, Tsukahara H, Ohshima Y, Ohta N, Tokuriki S, Tamura S, et al. High levels of growth factors in human breast milk. Early Hum Dev. (2008) 84:67-9. doi: 10.1016/j.earlhumdev.2007.07.005

72. LeBouder E, Rey-Nores JE, Raby AC, Affolter M, Vidal K, Thornton CA, et al. Modulation of neonatal microbial recognition: TLR-mediated innate immune responses are specifically and differentially modulated by human milk. J Immunol. (2006) 176:3742-52. doi: 10.4049/jimmunol.176.6.3742

73. Good M, Sodhi CP, Egan CE, Afrazi A, Jia H, Yamaguchi Y, et al. Breast milk protects against the development of necrotizing enterocolitis through inhibition of Toll-like receptor 4 in the intestinal epithelium via activation of the epidermal growth factor receptor. Mucosal Immunol. (2015) 8:1166-79. doi: 10.1038/mi.2015.30

74. Jones CA, Holloway JA, Popplewell EJ, Diaper ND, Holloway JW, Vance $\mathrm{GH}$, et al. Reduced soluble CD14 levels in amniotic fluid and breast milk are associated with the subsequent development of atopy, eczema, or both. $J$ Allergy Clin Immunol. (2002) 109:858-66. doi: 10.1067/mai.2002.123535

75. Savilahti EM, Kukkonen AK, Kuitunen M, Savilahti E. Soluble CD14, alpha-and beta-defensins in breast milk: association with the emergence of allergy in a high-risk population. Innate Immun. (2015) 21:332-7. doi: $10.1177 / 1753425914541560$

76. Koenig A, de Albuquerque Diniz EM, Barbosa SF, Vaz FA. Immunologic factors in human milk: the effects of gestational age and pasteurization. J Hum Lact. (2005) 21:439-43. doi: 10.1177/0890334405 280652

77. Jarvinen KM, Laine ST, Jarvenpaa AL, Suomalainen HK. Does low IgA in human milk predispose the infant to development of cow's milk 
allergy? Pediatr Res. (2000) 48:457-62. doi: 10.1203/00006450-20001000000007

78. Jarvinen KM, Westfall JE, Seppo MS, James AK, Tsuang AJ, Feustel PJ, et al. Role of maternal elimination diets and human milk IgA in the development of cow's milk allergy in the infants. Clin Exp Allergy (2014) 44:69-78. doi: 10.1111/cea.12228

79. Machtinger S, Moss R. Cow's milk allergy in breast-fed infants: the role of allergen and maternal secretory IgA antibody. J Allergy Clin Immunol. (1986) 77:341-7. doi: 10.1016/S0091-6749(86)80115-4

80. Savilahti E, Tainio VM, Salmenpera L, Arjomaa P, Kallio M, Perheentupa J, et al. Low colostral IgA associated with cow's milk allergy. Acta Paediatr Scand. (1991) 80:1207-13. doi: 10.1111/j.1651-2227.1991.tb11810.x

81. Renz H, Brandtzaeg P, Hornef M. The impact of perinatal immune development on mucosal homeostasis and chronic inflammation. Nat Rev Immunol. (2011) 12:9-23. doi: 10.1038/nri3112

82. Munblit D, Sheth S, Abrol P, Treneva M, Peroni DG, Chow LY, et al. Exposures influencing total IgA level in colostrum. J Dev Orig Health Dis. (2016) 7:61-7. doi: 10.1017/S2040174415001476

83. Kaetzel CS. Cooperativity among secretory IgA, the polymeric immunoglobulin receptor, and the gut microbiota promotes hostmicrobial mutualism. Immunol Lett. (2014) $162(2 \mathrm{Pt} . \quad \mathrm{A}): 10-21$. doi: 10.1016/j.imlet.2014.05.008

84. Hanson LA, Korotkova M. The role of breastfeeding in prevention of neonatal infection. Semin Neonatol. (2002) 7:275-81. doi: 10.1053/siny.2002.0124

85. Seppo AE, Savilahti EM, Berin MC, Sampson HA, Jarvinen KM. Breast milk IgA to foods has different epitope specificity than serum IgA-Evidence for entero-mammary link for food-specific IgA? Clin Exp Allergy (2017) 47:1275-84. doi: 10.1111/cea.12945

86. Roux ME, McWilliams M, Phillips-Quagliata JM, Weisz-Carrington P, Lamm ME. Origin of IgA-secreting plasma cells in the mammary gland. J Exp Med. (1977) 146:1311-22. doi: 10.1084/jem.146.5.1311

87. Hanson LA, Ahlstedt S, Carlsson B, Fallstrom SP, Kaijser B, Lindblad BS, et al. New knowledge in human milk immunoglobulin. Acta Paediatr Scand. (1978) 67:577-82. doi: 10.1111/j.1651-2227.1978.tb17805.x

88. Roux ME, McWilliams M, Phillips-Quagliata JM, Lamm ME. Differentiation pathway of Peyer's patch precursors of IgA plasma cells in the secretory immune system. Cell Immunol. (1981) 61:141-53. doi: 10.1016/0008-8749(81)90361-0

89. Dahlgren UI, Ahlstedt S, Hanson LA. The localization of the antibody response in milk or bile depends on the nature of the antigen. J Immunol. (1987) 138:1397-402.

90. Tanneau GM, Hibrand-Saint Oyant L, Chevaleyre CC, Salmon HP. Differential recruitment of T- and IgA B-lymphocytes in the developing mammary gland in relation to homing receptors and vascular addressins. $J$ Histochem Cytochem. (1999) 47:1581-92. doi: 10.1177/002215549904701210

91. Morteau O, Gerard C, Lu B, Ghiran S, Rits M, Fujiwara Y, et al. An indispensable role for the chemokine receptor CCR10 in IgA antibody-secreting cell accumulation. J Immunol. (2008) 181:6309-15. doi: 10.4049/jimmunol.181.9.6309

92. Peri BA, Theodore CM, Losonsky GA, Fishaut JM, Rothberg RM, Ogra PL. Antibody content of rabbit milk and serum following inhalation or ingestion of respiratory syncytial virus and bovine serum albumin. Clin Exp Immunol. (1982) 48:91-101.

93. Goldblum RM, Ahlstedt S, Carlsson B, Hanson LA, Jodal U, Lidin-Janson G, et al. Antibody-forming cells in human colostrum after oral immunisation. Nature (1975) 257:797-8. doi: 10.1038/257797a0

94. Azad MB, Konya T, Maughan H, Guttman DS, Field CJ, Chari RS, et al. Gut microbiota of healthy Canadian infants: profiles by mode of delivery and infant diet at 4 months. CMAJ (2013) 185:385-94. doi: 10.1503/cmaj.121189

95. Levin AM, Sitarik AR, Havstad SL, Fujimura KE, Wegienka G, CassidyBushrow AE, et al. Joint effects of pregnancy, sociocultural, and environmental factors on early life gut microbiome structure and diversity. Sci Rep. (2016) 6:31775. doi: 10.1038/srep31775

96. Yatsunenko T, Rey FE, Manary MJ, Trehan I, Dominguez-Bello MG, Contreras $\mathrm{M}$, et al. Human gut microbiome viewed across age and geography. Nature (2012) 486:222-7. doi: 10.1038/nature11053
97. Tamburini S, Shen N, Wu HC, Clemente JC. The microbiome in early life: implications for health outcomes. Nat Med. (2016) 22:713-22. doi: $10.1038 / \mathrm{nm} .4142$

98. Martina C, Looney RJ, Marcus C, Allen M, Stahlhut R. Prevalence of allergic disease in old order mennonites in New York. Ann Allergy Asthma Immunol. (2016). 117:562-3.e1. doi: 10.1016/j.anai.2016.08.023

99. Stein MM, Hrusch CL, Gozdz J, Igartua C, Pivniouk V, Murray SE, et al. Innate immunity and asthma risk in amish and hutterite farm children. $N$ Engl J Med. (2016) 375:411-21. doi: 10.1056/NEJMoa1508749

100. Bergstrom A, Skov TH, Bahl MI, Roager HM, Christensen LB, Ejlerskov $\mathrm{KT}$, et al. Establishment of intestinal microbiota during early life: a longitudinal, explorative study of a large cohort of Danish infants. Appl Environ Microbiol. (2014) 80:2889-900. doi: 10.1128/AEM. 00342-14

101. Subramanian S, Huq S, Yatsunenko T, Haque R, Mahfuz M, Alam $\mathrm{MA}$, et al. Persistent gut microbiota immaturity in malnourished Bangladeshi children. Nature (2014) 510:417-21. doi: 10.1038/nature 13421

102. Voreades N, Kozil A, Weir TL. Diet and the development of the human intestinal microbiome. Front Microbiol. (2014) 5:494. doi: 10.3389/fmicb.2014.00494

103. Backhed F, Roswall J, Peng Y, Feng Q, Jia H, Kovatcheva-Datchary $P$, et al. Dynamics and Stabilization of the Human Gut Microbiome during the First Year of Life. Cell Host Microbe (2015) 17:690-703. doi: 10.1016/j.chom.2015.04.004

104. Fernandez L, Langa S, Martin V, Maldonado A, Jimenez E, Martin R, et al. The human milk microbiota: origin and potential roles in health and disease. Pharmacol Res. (2013) 69:1-10. doi: 10.1016/j.phrs.2012. 09.001

105. Martin R, Heilig HG, Zoetendal EG, Jimenez E, Fernandez L, Smidt $\mathrm{H}$, et al. Cultivation-independent assessment of the bacterial diversity of breast milk among healthy women. Res Microbiol. (2007) 158:31-7. doi: 10.1016/j.resmic.2006.11.004

106. Hunt KM, Foster JA, Forney LJ, Schutte UM, Beck DL, Abdo Z, et al. Characterization of the diversity and temporal stability of bacterial communities in human milk. PLoS ONE (2011) 6:e21313. doi: 10.1371/journal.pone.0021313

107. Cabrera-Rubio R, Collado MC, Laitinen K, Salminen S, Isolauri E, Mira A. The human milk microbiome changes over lactation and is shaped by maternal weight and mode of delivery. Am J Clin Nutr. (2012) 96:544-51. doi: $10.3945 /$ ajcn.112.037382

108. Jost T, Lacroix C, Braegger C, Chassard C. Assessment of bacterial diversity in breast milk using culture-dependent and culture-independent approaches. Br J Nutr. (2013) 110:1253-62. doi: 10.1017/S0007114513 000597

109. Ward TL, Hosid S, Ioshikhes I, Altosaar I. Human milk metagenome: a functional capacity analysis. BMC Microbiol. (2013) 13:116. doi: 10.1186/1471-2180-13-116

110. Favier CF, Vaughan EE, De Vos WM, Akkermans AD. Molecular monitoring of succession of bacterial communities in human neonates. Appl Environ Microbiol. (2002) 68:219-26. doi: 10.1128/AEM.68.1.219-226.2002

111. Martin R, Langa S, Reviriego C, Jiminez E, Marin ML, Xaus J, et al. Human milk is a source of lactic acid bacteria for the infant gut. J Pediatr. (2003) 143:754-8. doi: 10.1016/j.jpeds.2003.09.028

112. Heikkila MP, Saris PE. Inhibition of Staphylococcus aureus by the commensal bacteria of human milk. J Appl Microbiol. (2003) 95:471-8. doi: 10.1046/j.1365-2672.2003.02002.x

113. Pannaraj PS, Li F, Cerini C, Bender JM, Yang S, Rollie A, et al. Association between breast milk bacterial communities and establishment and development of the infant gut microbiome. JAMA Pediatr. (2017) 171:647-54. doi: 10.1001/jamapediatrics.2017.0378

114. Sela DA, Chapman J, Adeuya A, Kim JH, Chen F, Whitehead TR, et al. The genome sequence of Bifidobacterium longum subsp. infantis reveals adaptations for milk utilization within the infant microbiome. Proc Natl Acad Sci USA. (2008) 105:18964-9. doi: 10.1073/pnas.0809584105

115. Turroni F, Bottacini F, Foroni E, Mulder I, Kim JH, Zomer A, et al. Genome analysis of Bifidobacterium bifidum PRL2010 reveals metabolic pathways for 
host-derived glycan foraging. Proc Natl Acad Sci USA. (2010) 107:19514-9. doi: 10.1073/pnas.1011100107

116. Yu ZT, Chen C, Kling DE, Liu B, McCoy JM, Merighi M, et al. The principal fucosylated oligosaccharides of human milk exhibit prebiotic properties on cultured infant microbiota. Glycobiology (2013) 23:169-77. doi: $10.1093 / \mathrm{glycob} / \mathrm{cws} 138$

117. He Y, Liu S, Leone S, Newburg DS. Human colostrum oligosaccharides modulate major immunologic pathways of immature human intestine. Mucosal Immunol. (2014) 7:1326-39. doi: 10.1038/mi.2014.20

118. Kuntz S, Kunz C, Rudloff S. Oligosaccharides from human milk induce growth arrest via G2/M by influencing growth-related cell cycle genes in intestinal epithelial cells. Br J Nutr. (2009) 101:1306-15. doi: 10.1017/S0007114508079622

119. Naarding MA, Ludwig IS, Groot F, Berkhout B, Geijtenbeek TB, Pollakis $\mathrm{G}$, et al. Lewis X component in human milk binds DC-SIGN and inhibits HIV-1 transfer to CD4+ T lymphocytes. J Clin Invest. (2005) 115:3256-64. doi: $10.1172 /$ JCI25105

120. Ninonuevo MR, Perkins PD, Francis J, Lamotte LM, LoCascio RG, Freeman SL, et al. Daily variations in oligosaccharides of human milk determined by microfluidic chips and mass spectrometry. J Agric Food Chem. (2008) 56:618-26. doi: 10.1021/jf071972u

121. Erney RM, Malone WT, Skelding MB, Marcon AA, Kleman-Leyer KM, O'Ryan ML, et al. Variability of human milk neutral oligosaccharides in a diverse population. J Pediatr Gastroenterol Nutr. (2000) 30:181-92. doi: 10.1097/00005176-200002000-00016

122. Castanys-Munoz E, Martin MJ, Prieto PA. 2'-fucosyllactose: an abundant, genetically determined soluble glycan present in human milk. Nutr Rev. (2013) 71:773-89. doi: 10.1111/nure.12079

123. Lewis ZT, Totten SM, Smilowitz JT, Popovic M, Parker E, Lemay $\mathrm{DG}$, et al. Maternal fucosyltransferase 2 status affects the gut bifidobacterial communities of breastfed infants. Microbiome (2015) 3:13. doi: 10.1186/s40168-015-0071-z

124. Newburg DS, Ruiz-Palacios GM, Altaye M, Chaturvedi P, MeinzenDerr J, Guerrero Mde L, et al. Innate protection conferred by fucosylated oligosaccharides of human milk against diarrhea in breastfed infants. Glycobiology (2004) 14:253-63. doi: 10.1093/glycob/ cwh020

125. Morrow AL, Ruiz-Palacios GM, Jiang X, Newburg DS. Human-milk glycans that inhibit pathogen binding protect breast-feeding infants against infectious diarrhea. J Nutr. (2005) 135:1304-7. doi: 10.1093/jn/135. 5.1304

126. Bode L, Kuhn L, Kim HY, Hsiao L, Nissan C, Sinkala M, et al. Human milk oligosaccharide concentration and risk of postnatal transmission of HIV through breastfeeding. Am J Clin Nutr. (2012) 96:831-9. doi: $10.3945 /$ ajen.112.039503

127. Van Niekerk E, Autran CA, Nel DG, Kirsten GF, Blaauw R, Bode L. Human milk oligosaccharides differ between HIV-infected and HIVuninfected mothers and are related to necrotizing enterocolitis incidence in their preterm very-low-birth-weight infants. J Nutr. (2014) 144:1227-33. doi: $10.3945 /$ jn. 113.187799

128. Kuhn L, Kim HY, Hsiao L, Nissan C, Kankasa C, Mwiya M, et al. Oligosaccharide composition of breast milk influences survival of uninfected children born to HIV-infected mothers in Lusaka, Zambia. J Nutr. (2015) 145:66-72. doi: 10.3945/jn.114.199794

129. Seppo AE, Autran CA, Bode L, Jarvinen KM. Human milk oligosaccharides and development of cow's milk allergy in infants. J Allergy Clin Immunol. (2017) 139:708-11 e705. doi: 10.1016/j.jaci.2016.08.031

130. Sjögren YM, Duchén K, Lindh F, Björkstén B, Sverremark-Ekström E. Neutral oligosaccharides in colostrum in relation to maternal allergy and allergy development in children up to 18 months of age. Pediatric Allergy Immunol. (2007) 18:20-6. doi: 10.1111/j.1399-3038.2006.00486.x

131. Miliku K, Robertson B, Sharma AK, Subbarao P, Becker AB, Mandhane PJ, et al. Human milk oligosaccharide profiles and food sensitization among infants in the CHILD Study. Allergy (2018). doi: 10.1111/all.13476

132. Cacho NT, Lawrence RM. Innate immunity and breast milk. Front Immunol. (2017) 8:584. doi: 10.3389/fimmu.2017.00584

133. Dunstan JA, Roper J, Mitoulas L, Hartmann PE, Simmer K, Prescott SL. The effect of supplementation with fish oil during pregnancy on breast milk immunoglobulin A, soluble CD14, cytokine levels and fatty acid composition. Clin Exp Allergy (2004) 34:1237-42. doi: $10.1111 / j .1365-2222.2004 .02028 . x$

134. Yu G, Duchen K, Bjorksten B. Fatty acid composition in colostrum and mature milk from non-atopic and atopic mothers during the first 6 months of lactation. Acta Paediatr. (1998) 87:729-36. doi: 10.1111/j.1651-2227.1998.tb01738.x

135. Reichardt P, Muller D, Posselt U, Vorberg B, Diez U, Schlink U, et al. Fatty acids in colostrum from mothers of children at high risk of atopy in relation to clinical and laboratory signs of allergy in the first year of life. Allergy (2004) 59:394-400. doi: 10.1111/j.1398-9995.2003.00429.x

136. Stoney RM, Woods RK, Hosking CS, Hill DJ, Abramson MJ, Thien FC. Maternal breast milk long-chain n-3 fatty acids are associated with increased risk of atopy in breastfed infants. Clin Exp Allergy (2004) 34:194-200. doi: $10.1111 / j .1365-2222.2004 .01852 . x$

137. Laitinen K, Sallinen J, Linderborg K, Isolauri E. Serum, cheek cell and breast milk fatty acid compositions in infants with atopic and non-atopic eczema. Clin Exp Allergy (2006) 36:166-73. doi: 10.1111/j.1365-2222.2006. 02417.x

138. Oddy WH, Pal S, Kusel MM, Vine D, de Klerk NH, Hartmann P, et al. Atopy, eczema and breast milk fatty acids in a high-risk cohort of children followed from birth to 5 yr. Pediatr Allergy Immunol. (2006) 17:4-10. doi: 10.1111/j.1399-3038.2005.00340.x

139. Wijga AH, van Houwelingen AC, Kerkhof M, Tabak C, de Jongste JC, Gerritsen J, et al. Breast milk fatty acids and allergic disease in preschool children: the prevention and incidence of asthma and mite allergy birth cohort study. J Allergy Clin Immunol. (2006) 117:440-7. doi: $10.1016 /$ j.jaci.2005.10.022

140. Harbige LS. Fatty acids, the immune response, and autoimmunity: a question of $n-6$ essentiality and the balance between $n-6$ and n-3. Lipids (2003) 38:323-41. doi: 10.1007/s11745-003-1067-z

141. Kumari M, Kozyrskyj AL. Gut microbial metabolism defines host metabolism: an emerging perspective in obesity and allergic inflammation. Obes Rev. (2017) 18:18-31. doi: 10.1111/obr.12484

142. Rasmussen HS, Holtug K, Ynggard C, Mortensen PB. Faecal concentrations and production rates of short chain fatty acids in normal neonates. Acta Paediatr Scand. (1988) 77:365-8. doi: 10.1111/j.1651-2227.1988.tb10661.x

143. Tan J, McKenzie C, Vuillermin PJ, Goverse G, Vinuesa CG, Mebius RE, et al. Dietary fiber and bacterial SCFA enhance oral tolerance and protect against food allergy through diverse cellular pathways. Cell Rep. (2016) 15:2809-24. doi: 10.1016/j.celrep.2016.05.047

144. Bridgman SL, Azad MB, Field CJ, Haqq AM, Becker AB, Mandhane PJ, et al. Fecal Short-Chain Fatty Acid Variations by Breastfeeding Status in Infants at 4 Months: Differences in Relative versus Absolute Concentrations. Front Nutr. (2017) 4:11. doi: 10.3389/fnut.2017.00011

145. Patki S, Kadam S, Chandra V, Bhonde R. Human breast milk is a rich source of multipotent mesenchymal stem cells. Hum Cell (2010) 23:35-40. doi: 10.1111/j.1749-0774.2010.00083.x

146. Moles JP, Tuaillon E, Kankasa C, Bedin AS, Nagot N, Marchant A, et al. Breastmilk cell trafficking induces microchimerism-mediated immune system maturation in the infant. Pediatr Allergy Immunol. (2018) 29:133-43. doi: 10.1111/pai.12841

147. Jarvinen KM, Suomalainen H. Leucocytes in human milk and lymphocyte subsets in cow's milk-allergic infants. Pediatr Allergy Immunol. (2002) 13:243-54. doi: 10.1034/j.1399-3038.2002.00087.x

148. Troncone R, Scarcella A, Donatiello A, Cannataro P, Tarabuso A, Auricchio S. Passage of gliadin into human breast milk. Acta Paediatr Scand. (1987) 76:453-6. doi: 10.1111/j.1651-2227.1987.tb10498.x

149. Sorva R, Makinen-Kiljunen S, Juntunen-Backman K. Beta-lactoglobulin secretion in human milk varies widely after cow's milk ingestion in mothers of infants with cow's milk allergy. J Allergy Clin Immunol. (1994) 93:787-92. doi: 10.1016/0091-6749(94)90259-3

150. Jarvinen KM, Makinen-Kiljunen S, Suomalainen H. Cow's milk challenge through human milk evokes immune responses in infants with cow's milk allergy. J Pediatr. (1999) 135:506-12. doi: 10.1016/S0022-3476(99)70175-7

151. Vadas P, Wai Y, Burks W, Perelman B. Detection of peanut allergens in breast milk of lactating women. JAMA (2001) 285:1746-8. doi: 10.1001/jama.285.13.1746 
152. Palmer DJ, Gold MS, Makrides M. Effect of cooked and raw egg consumption on ovalbumin content of human milk: a randomized, double-blind, cross-over trial. Clin Exp Allergy (2005) 35:173-8. doi: 10.1111/j.1365-2222.2005.02170.x

153. Palmer DJ, Gold MS, Makrides M. Effect of maternal egg consumption on breast milk ovalbumin concentration. Clin Exp Allergy (2008) 38:1186-91. doi: 10.1111/j.1365-2222.2008. 03014.x

154. Bernard H, Ah-Leung S, Drumare MF, Feraudet-Tarisse C, Verhasselt V, Wal JM, et al. Peanut allergens are rapidly transferred in human breast milk and can prevent sensitization in mice. Allergy (2014) 69:888-97. doi: 10.1111/all.12411

155. Metcalfe JR, Marsh JA, D’Vaz N, Geddes DT, Lai CT, Prescott SL, et al. Effects of maternal dietary egg intake during early lactation on human milk ovalbumin concentration: a randomized controlled trial. Clin Exp Allergy (2016) 46:1605-13. doi: 10.1111/cea.12806

Conflict of Interest Statement: The authors declare that the research was conducted in the absence of any commercial or financial relationships that could be construed as a potential conflict of interest.

Copyright (C) 2018 Rajani, Seppo and Järvinen. This is an open-access article distributed under the terms of the Creative Commons Attribution License (CC BY).

The use, distribution or reproduction in other forums is permitted, provided the original author(s) and the copyright owner(s) are credited and that the original publication in this journal is cited, in accordance with accepted academic practice. No use, distribution or reproduction is permitted which does not comply with these terms. 